\title{
PENGARUH MODEL PEMBELAJARAN BRAIN BASED LEARNING TERHADAP AKTIVITAS BELAJAR PAI SISWA
}

\author{
Diki Ibrahim ${ }^{1)}$ \\ 1) UIN Sunan Gunung Djati Bandung, Jalan A.H. Nasution No. 105, Cipadung, Cibiru, \\ Cipadung, Cibiru, Kota Bandung, Jawa Barat 40614 \\ Email: dikiibrahim1996@gmail.com
}

\begin{abstract}
This observation against the background of the problems of unconfident from students to the active, explain material and summarize what has been learned. The uncondusive of condition of learn, causing lack of student learning activities. The purpose of this observations is to know the reality of student learning activity by using brain based learning method, the reality of student learning activity by using the conventional methode, also the effect of brain based learning methode on students. Method of this observations is Quasi Experiment. The brain based learning methode is a methode learning method that aligns learning in accordance woth students brain performance. The activities of student learning with brain based learning methode on class experimental class interpreted is high. And the results on class control interpreted is middle. The influence is according with the result of N-Gain calculation is equal to 0,56, the figure is included the medium category.
\end{abstract}

Keywords:

Brain Based Learning, Students Learning Activity, PAI

\begin{abstract}
Abstrak : Penelitian ini dilatar belakangi oleh masalah yang menunjukkan kurangnya rasa percaya diri siswa untuk dapat aktif, menjelaskan materi, dan menyimpulkan apa yang telah dipelajari. Kondisi pembelajaran yang tidak kondusif, menyebabkan kurangnya aktivitas belajar siswa. Tujuan penelitian ini adalah untuk mengetahui realitas aktivitas belajar siswa dengan menggunakan model pembelajaran brain based learning, realitas aktivitas belajar siswa dengan menggunakan model pembelajaran konvensional serta pengaruh model pembelajaran brain based learning terhadap aktivitas belajar siswa di kelas VIII SMPN 2 Cileunyi. Metode penelitian ini adalah metode penelitian Quasi Experiment. Model pembelajaran Brain Based Learning merupakan model pembelajaran yang menyelaraskan pembelajaran sesuai dengan kinerja otak siswa. Berdasarkan hasil penelitian diketahui bahwa aktivitas belajar siswa dengan menggunakan model pembelajaran brain based learning pada kelas eksperimen diinterpretasikan tinggi, hal tersebut didapatkan dari hasil aktivitas belajar siswa sebesar 3,70. Sementara itu hasil aktivitas belajar siswa pada kelas kontrol diinterpretasikan sedang, hal tersebut didapatkan dari hasil aktivitas belajar siswa sebesar 2,92. Adapun pengaruh tersebut sesuai dengan hasil perhitungan $\mathrm{N}$-gain yaitu sebesar 0,56, angka tersebut termasuk pada kategori sedang yang berarti pengaruh model pembelajaran brain based learning terhadap aktivitas belajar siswa memiliki pengaruh yang sedang.
\end{abstract}

Kata kunci:

Brain Based Learning, Aktivitas Belajar Siswa, PAI

\section{PENDAHULUAN}

Pendidikan merupakan usaha sadar dan terencana untuk menciptakan suasana belajar dan proses pembelajaran agar siswa dapat secara aktif mengembangkan potensi dirinya untuk memiliki kekuatan spiritual keagamaan, pengendalian diri, kepribadian, kecerdasan, akhlak mulia, serta keterampilan yang diperlukan dirinya, masyarakat, bangsa dan negara (Aulia, 2009:10). 
Dalam arti lain Pendidikan adalah usaha membina dan membentuk pribadi siswa agar bertakwa kepada Allah SWT cinta kasih kepada orang tua dan sesamanya, dan pada tanah airnya, sebagai karunia yang diberikan oleh Allah SWT (Tatang, 2012:15).

Dari dua pengertian di atas menegaskan bahwa pendidikan merupakan hal yang sangat penting dalam kehidupan ini, oleh karena itu pendidikan harus dilaksanakan dengan baik agar menciptakan pendidikan yang bermutu yang menghasilkan generasi berikutnya yang cerdas, bermoral, dan berkepribadian. Untuk itu perlu dirancang sistem pendidikan yang mampu menciptakan suasana dan proses pembelajaran yang menyenangkan, merangsang dan menantang siswa untuk mengembangkan diri secara optimal sesuai dengan bakat dan kemampuannya.

Sebagaimana kurikulum yang berlaku saat ini ialah kurikulum nasional dimana pembelajaran tidak lagi berpusat pada seorang guru melainkan pembelajaran yang berpusat pada siswa sendiri, sedangkan guru menjadi seorang fasilitator pembelajaran bagi siswa. Pembelajaran yang dilaksanakan di SMP Negeri 2 Cileunyi sendiri telah menggunakan kurikulum nasional atau yang kerap disebutu kurikulum 2013 di beberapa tahun terakhir, namun hasil pengamatan awal peneliti bahwa pembelajaran PAI yang dilaksanakan di kelas VIII masih kurang menantang bagi aktivitas belajar siswa.

Meskipun pembelajaran telah menggunakan pembelajaran yang berpusat pada siswa, masih banyak ditemukan siswa yang tidak mengikuti jalannya pembelajaran seperti; tidak mendengarkan saat guru menjelaskan atau teman sebayanya menjelaskan di depan kelas, tidak berani mengungkapkan pendapatnya, tidak berani untuk bertanya jika tidak tahu. Hal tersebut berimplikasi pada proses dan hasil belajar yang tidak optimal karena kurangnya aktivitas belajar siswa.

Selain itu, aktivitas belajar siswa kelas VIII pada mata pelajaran PAI tidak berjalan sesuai yang diharapkan dikarenakan adanya rasa takut dalam diri siswa, sehingga siswa tidak mampu mengeluarkan kemampuan yang dimilikinya dalam proses pembelajaran dan ia merasa tidak percaya diri untuk dapat mengikuti pembelajaran. Sikap takut dan merasa terancam saat proses pembelajaran sedang berlangsung tersebut terjadi karena ketidak pedulian seorang guru dalam proses pembelajaran yang tidak memperhatikan siswanya untuk tidak saling memojokan sesama siswa. Maka dari itu guru perlu menciptakan suasana yang aman dan mengeluarkan siswa dari rasa takut dan terancam pada saat proses pembelajaran agar pembelajaran dapat berlangsung secara baik.

Menghadapi permasalahan tersebut, hendaknya guru mengubah pola pembelajaran yang mampu melibatkan anak secara aktif, melakukan, mencari, dan mengolah sendiri. Selain itu guru hendak menyelaraskan pembelajaran dengan kemampuan berpikir otak setiap siswa, karena tidak sedikit guru yang tidak memperhatikan hal tersebut. Adapun pola pembelajaran yang harus dirubah adalah dengan mengganti pola pembelajaran yang konvensional menjadi pembelajaran berbasis otak atau Brain Based Learning.

Secara umum penelitian ini bertujuan untuk menerapkan model pembelajaran brain based learning pada mata pelajaran PAI bagi siswa SMP Secara lebih khusus 
penelitian ini bertujuan : 1) Untuk mengetahui realitas aktivitas belajar siswa pada mata pelajaran PAI yang menggunakan model pembelajaran Brain Based Learning pada kelas eksperimen. 2) Untuk mengetahui realitas aktivitas belajar siswa yang menggunakan model pembelajaran konvensional pada kelas kontrol. 3) Untuk mengetahui pengaruh penerapan model pembelajaran Brain Based Learning terhadap aktivitas belajar siswa Kelas VIII SMPN 2 Cileunyi pada mata pelajaran PAI.

Dalam pembelajaran, guru kerap kali mengalami berbagai permasalahan. Oleh karena itu, untuk mengatasi berbagai masalah dalam pembelajaran perlu adanya sebuah rancangan pembelajaran yang dijadikan sebagai pedoman pembelajaran. Istilah tersebut sering kita sebut dengan model pembelajaran.

Menurut Trianto (2012: 52), model pembelajaran merupakan suatu perencanaan yang dapat di gunakan untuk mendesain pola-pola mengajar secara tatap muka di dalam kelas atau mengatur tutorial, dan untuk menentukan material/ perangkat pembelajaran termasuk di dalamnya buku-buku, film-film, tipe-tipe, program-program media komputer, dan kurikulum (sebagai kursus untuk belajar). Setiap model mengarahkan kita untuk mendesain pembelajaran yang dapat membantu siswa untuk mencapai berbagai tujuan.

Joce dan Weil (1992: 1) menyatakan bahwa: "Model of teaching are really model of learning. As we help students acquire information, ideas, skill, value, ways of thinking and means of expressing themselves, we are also teaching them how to learn". Hal ini berarti bahwa model mengajar merupakan model belajar dengan model tersebut guru dapat membantu siswa untuk mendapatkan atau memperoleh informasi, ide, keterampilan, cara berpikir, dan mengekspresikan ide diri sendiri. Selain itu, mereka juga mengajarkan bagaimana mereka belajar (Trianto, 2012 :51).

Dengan demikian, dapat kita simpulkan bahwa model pembelajaran merupakan kerangka konseptual prosedur sistematis dalam pembelajaran. Sehingga tujuan pembelajaran yang telah ditentukan dapat tercapai dengan baik.

Menurut (Jensen, 2008: 12), Brain based learning merupakan model pembelajaran yang menyelaraskan otak untuk belajar secara alamiah, juga mempertimbangkan bagaimana otak bekerja saat mengambil, mengolah, dan menginterpretasikan informasi yang telah diserap. Selain itu model pembelajaran Brain Based Learning memiliki tiga prinsip utama, yakni; menciptakan pembelajaran yang menghindarkan siswa dari rasa takut saat pembelajaran, menciptakan pembelajaran yang menantang siswa untuk aktif mengikuti pembelajaran, dan menciptakan pembelajaran yang melibatkan pengalaman siswa secara langsung.

Dalam penerapannya, model pembelajaran brain based learning memiliki tahapan-tahapan perencanaan pembelajaran antara lain:

1. Tahap pra pemaparan,

Tahap pra pemaparan ini merupakan tahap dimana seorang guru memberikan gambaran umum melalui media mind map mengenai materi pembelajaran yang akan dilaksanakan.

2. Tahap persiapan, 
Tahapan selanjutanya ialah guru menyiapkan kondisi kelas agar siswa merasa tertarik untuk mengikuti pembelajaran. Selain itu pada tahap ini guru berusaha untuk mengaitkan materi pembelajaran yang akan dilaksanakan dengan realita yang ada dalam kehidupan sehari-hari.

3. Tahap inisiasi dan akuisisi,

Pada tahap ini, guru dituntut untuk memberikan sedikit penjelasan kepada siswa dan membimbingnya untuk mencari informasi mengenai materi yang dipelajari dan memahami materi tersebut.

4. Tahap elaborasi,

Tahap ini merupakan tahap pemrosesan, dimana siswa diberi leluasa untuk mencari, menyaring, menganalisis, dan memperdalam materi pembelajaran. Hal ini merupakan saatnya untuk membuat kesan intelektual dalam pembelajaran.

5. Tahap inkubasi dan memasukan memori,

Tahap ini menekankan pentinya waktu istirahat dan waktu untuk mengulang kembali. Otak belajar paling efektif dari waktu ke waktu bukan, bukan langsung pada suatu saat.

6. Tahap verifikasi dan pengecekan keyakinan

Pada tahap ini guru mengecek apakah siswa sudah paham dengan materi yang dipelajari atau belum, begitupun siswa merasa dirinya sudah mengerti dengan apa yang telah dipelajari atau belum.

7. Tahap perayaan dan integrasi.

Pada tahap ini sangat penting untuk melibatkan emosi. Pembelajaran akan terasa sangat berkesan bagi siswa jika apa yang telah mereka perjuangkan diberi penghargaan. Selain itu dari bentuk penghargaan, perayaan kecil pun diperlukan agar pembelajaran ditutup dengan hal yang menyenangkan.

Menurut Caine (dalam Jurnal JMS Aziz, dkk, 2012 : 114) model pembelajaran brain based learning memiliki 12 prinsip, diantaranya:

a) The brain is a parallel processor (Otak merupakan prosesor paralel).

b) Learning engages the entire physiology (Belajar melibatkan seluruh tubuh).

c) The search for meaning is innate (Pencarian makna merupakan bawaan).

d) The search for meaning occurs through "patterning" (Pencarian makna terjadi melalui pembuatan pola).

e) Emotion are critical to patterning (Emosi sangat penting untuk pembuatan pola).

f) Every brain simultaneously perceives and creates parts and wholes (Setiap otak memproses keseluruhan dan bagian-bagian secara serentak).

g) Learning involves both focused attention and peripheral perception (Belajar melibatkan pemusatan perhatian dan persepsi sekeliling).

h) Learning always involves conscious and unconscious processes (Belajar selalu melibatkan proses sadar maupun tidak sadar).

i) We have ( at least) two types of memory systems: spatial and rote learning (Manusia paling sedikit dua jenis sistem memori, yaitu spasial dan hafalan). 
j) The brain understands and remembers best when facts and skills are embedded in natural spatial memory (Otak mengerti dan mengingat paling baik ketika fakta-fakta dan keterampilan tertanam dalam memori spasial).

k) Learning is enhanced by challenge and inhibbited by threat (Pembelajaran ditingkatkan oleh tantangan dan dihambat oleh ancaman).

1) Every brain is unique (Setiap otak adalah unik).

Prinsip model pembelajaran brain based learning ini menjelaskan bahwa otak setiap manusia memiliki potensi untuk terus berkembang, maka dari itu guru perlu memperhatikan hal tersebut. Otak merupakan bagian tubuh yang berukuran kecil tetapi memiliki fungsi yang sangat penting bagi manusia. Otak dapat menggerakan seluruh bagian tubuh manusia untuk dapat beraktivitas termasuk belajar. Maka dari itu otak dinyatakan sebagai sesuatu yang unik.

Dengan prinsip-prinsip di atas dapat memberikan dampak positif bagi siswa, seperti memiliki daya ingat yang kuat, pembelajaran yang menarik dan berkesan karena melibatkan pengalaman langsung maupun pemberian fakta-fakta yang nyata dalam kehidupan, serta memberikan pembelajaran yang menantang bagi siswa.

Eric jensen menyatakan beberapa kelebihan dan kekurang dari model pembelajaran brain based learning;

Beberapa kelebihan dari model pembelajaran brain based learning:

a) Menciptakan lingkungan belajar yang menantang kemampuan berpikir siswa.

b) Menciptakan lingkungan pembelajaran yang menyenangkan,

c) Menciptakan situasi pembelajaran yang aktif dan berkmana bagi siswa.

Pembelajaran dengan menggunakan model brain based learning dapat menciptakan pembelajaran yang aktif, menantang, dan menyenangkan bagi siswa, karena guru berusaha untuk menciptakan pembelajaran yang menyesuaikan dengan kinerja otak siswa. Sedangkan beberapa kekurangan dari model pembelajaran brain based learning yaitu:

a) Memerlukan waktu yang tidak sedikit untuk dapat memahami bagaimana otak kita bekerja dalam memahami suatu permasalahan,

b) Memerlukan fasilitas yang memadai dalam mendukung praktek pembelajaran,

c) Memerlukan biaya yang tidak sedikit dalam menciptakan lingkungan pembelajaran yang baik bagi otak.

Dalam penggunaan model pembelajaran brain based learning, ada beberapa hal yang perlu diperhatikan, yaitu : lingkungan, gerakan dan olahraga, musik, peta pikiran (Mind map), dan penampilan guru. Hal-hal tersebut sangat berpengaruh pada proses pembelajaran.

a) Lingkungan

Jensen (2008: 82) mengemukakan bahwa lingkungan pembelajaran yang dirancang dengan baik dapat merangsang pembelajaran dan mengurangi masalah disiplin. Relasi fasilitator pembelajaran dalam pendidikan merupakan hal yang sangat penting bagi lingkungan pembelajaran. Fasilitas kegiatan belajar yang memadai merupakan kondisi yang penting bagi siswa dalam sebuah pembelajaran. 
b) Gerakan dan Olahraga

Gerakan fisik bisa melakukan beberapa hal untuk otak. Pertama meningkatkan sirkulasi sehingga saraf-saraf individual bisa mendapatkan lebih banyak oksigen dan nutrisi. Kedua, bisa memacu produksi faktor pertumbuhan saraf, hormon yang meningkatkan fungsi otak. Ketiga, latihan fisik dapat meningkatkan sel baru di otak. (Jensen, 2008:260)

c) Musik

Musik merupakan salah satu media pembelajaran yang dapat memberikan dampak positif pada pembelajaran. Hal ini dikarenakan musik merupakan salah satu cara untuk merangsang pikiran, sehingga siswa dapat menerima materi pelajaran. Selain itu musik dapat memperbaiki konsentrasi, ingatan, meningkatkan aspek kognitig, fisiologis dan juga kecerdasan emosional.

d) Peta Pikiran (Mind Map)

Peta pikiran atau yang sering disebut Mind map merupakan metode yang tepat dalam pelaksanaan kegiatan pendahuluan sebuah pembelajaran (Jensen, 2008:134). Penggunaan warna, gambar dan bentuk yang menarik memaksimalkan potensi pikiran manusia dengan menggunakan otak kanan dan kirinya. Mind map dapat dimanfaatkan untuk berbagai kepentingan, baik yang bersifat personal maupun kolaboratif. Dalam konteks pembelajaran, mind map dapat digunakan untuk membantu siswa dalam memahami, mengorganisasikan dan memvisualisasikan materi dan aktivitas belajarnya secara kreatif dan atraktif.

e) Penampilan Guru

Guru memiliki peranan penting dalam pembelajaran. Oleh karena itu guru dituntut untuk aktif, kreatif, dan bersahabat dengan siswa dalam pembelajaran yang menggunakan model pembelajaran brain based learning. Jensen (2008: 268) memberikan saran untuk menggunakan pendekatan sebagai berikut:

1) Guru menciptakan hubungan dan relasi yang positif dengan siswa.

2) Suasana pembelajaran bersifat kooperatif, lucu, aktif, dan menyenangkan.

3) Guru membangun lingkungan yang saling menghargai

4) Guru memberikan instruksi imperatif kepada siswa dalam komando, tetapi dengan cara yang lembut.

5) Siswa menanggapi cepat tanpa menganalisis inputnya.

Pernyataan diatas dapat disimpulkan bahwa guru harus dihormati tetapi tetap bersahaja dengan siswa, guru menjadikan dirinya seorang mitra dan fasilitator pembelajaran bagi siswa. Dengan demikian guru dapat menjalin relasi yang baik dengan para siswa.

Model pembelajaran ini akan terhambat atau tidak dapat terlaksana dengan baik jika fasilitas yang ada sekolah kurang memadai, selain itu faktor fisik dan psikis pun dapat menghambat proses pembelajaran yang menggunakan model brain based learning.

Menurut Wina Sanjaya (2009: 177) (dalam jurnal Pendidikan Teknik Elektro, Setiyowati dan Pramukantoro, 2014:156) Model pembelajaran konvensional adalah 
pembelajaran yang menekankan pada penyampaian materi secara verbal dari seorang guru kepada siswa saat pembelajaran dikelas yang bertujuan agar siswa dapat menguasai secara optimal materi yang disampaikan.

Pembelajaran konvensional biasanya dilakukan dengan gaya guru berceramah di depan kelas menjelaskan materi pembelajaran hingga awal sampai akhir pelajaran berakhir, dan pada akhir pembelajaran guru biasanya memberikan tugas untuk siswa.

Menurut Hartono (dalam Jurnal Kesehatan Samodra Ilmu, Rochmawati, 2014: 106) model pembelajaran konvensional mempunyai ciri sebagai berikut:

a) Pembelajaran yang berpusat pada guru

b) Pembelajaran yang menekankan pada pengetahuan

c) Pembelajaran yang monoton

d) Pembelajaran yang tidak menyenangkan

e) Proses pembelajaran kurang memberdayakan semua indera dan potensi siswa

f) Media pembelajaran tidak banyak digunakan

g) Pembelajaran tidak perlu disesuaikan dengan pengetahuan yang ada

Hal tersebut menjelaskan bahwa model pembelajaran konvensional merupakan model pembelajaran yang dapat digunakan untuk semua materi pembelajaran, namun pembelajaran yang berlangsung terasa kurang menyenangkan karena pembelajaran yang dilaksanakan monoton dan berpusat pada guru. Siswa hanya fokus pada mendengarkan apa yang disampaikan guru, hal tersebut dapat berdampak negatif bagi siswa. Penggunaan model pembelajaran konvensional lebih mengirit biaya operasional pembelajaran, karena tidak perlu menggunkan banyak media pembelajaran. Oleh karena itu banyak guru yang lebih senang menggunakan model pembelajaran ini, dikarenakan guru tidak perlu repot untuk menyiapkan media pembelajaran yang akan digunakan.

Adapun tahap-tahap proses pembelajaran melalu model pembelajaran konvensional ialah sebagai berikut:

a) Tahap Menyampaikan Tujuan

Pada tahap ini, guru menyampaikan tujuan pembelajaran yang hendak dicapai oleh siswa pada proses pembelajaran tersebut. Penyampaian tujuan pembelajaran ini bisa disajikan dengan mengaitkan materi pembelajaran yang akan dipelajari dengan fakta-fakta yang ada dalam kehidupan sehari-hari.

b) Tahap Menyajikan Informasi

Pada tahap kedua, guru menyampaikan materi pembelajaran kepada siswa dengan menggunakan metode ceramah secara tahap demi tahap dan berurutan. Guru berusaha keras untuk mengolah materi pembelajaran agar dapat disampaikan dengan baik dan jelas, sehingga peserta didik yang memperhatikan dan mendengarkan dapat memahami materi tersebut dengan cepat.

c) Tahap Mengecek Pemahaman dengan Umpan balik

Pada tahap ini, guru mengecek pemahaman siswa dengan memberikan tugas yang dapat berupa lembar kerja siswa (LKS), dan memeriksa hasil tersebut secara bersama-sama. Kemudian guru memberikan umpan balik kepada siswa berupa reward yang dapat disajikan dengan bersorak atau tepuk tangan, dan pemberian ancaman bagi 
siswa yang mendapatkan hasil yang buruk agar termotivasi lebih baik pada pembelajaran berikutnya.

d) Tahap Memberikan Kesempatan untuk Latihan Lanjutan

Pada tahap terakhir, guru memberikan tugas sebagai bentuk dari latihan lanjutan agar siswa dapat semakin memahami materi pembelajaran yang telah dilaksanakan. (dalam jurnal Pendidikan Teknik Elektro, Setiyowati dan Pramukantoro, 2014:157)

Dengan demikian model pembelajaran konvensional merupakan model pembelajaran yang proses pembelajarannya terdiri 4 tahapan, yaitu tahap menyampaikan tujuan, tahap menyajikan informasi, tahap mengecek pemahaman dengan umpan balik, dan terakhir tahap memberikan informasi.

Adapun kelebihan dan kekurangan model pembelajaran konvensional menurut Rochmawati (dalam jurnal kesehatan Samodra Ilmu, 2014: 106) adalah sebagai berikut:

a) Kelebihan Model Pembelajaran Konvensional

1) Mempermudah menemukan informasi diberbagai tempat,

2) Menyampaikan informasi dengan cepat,

3) Membangkitkan minat akan informasi,

4) Mengajari siswa cara belajar dengan mendengarkan

5) Mudah digunakan dalam proses belajar mengajar

b) Kekurangan Model Pembelajaran Konvensional

1) Tidak semua siswa memiliki gaya belajar yang baik melalu mendengarkan

2) Kesulitan menjaga ketertarikan siswa dengan apa yang dipelajari,

3) Siswa tidak mengetahui tujuan pembelajaran yang dilaksanakan,

4) Penekanan belajar hanya pada penyelesaian tugas dan kurangnya daya ingat.

Dengan demikian model pembelajaran konvensional merupakan model pembelajaran yang sangat mudah untuk digunakan oleh guru dalam proses belajar mengajar. Guru tidak perlu susah payah untuk menyiapkan media pembelajaran yang akan digunakan, karena guru dapat menyampaikan informasi secara verbal dan cepat.

Namun, pembelajaran akan terasa tidak menyenangkan bagi siswa karena siswa tidak dapat mempertahankan minat belajarnya yang membuat siswa bosan dan mengantuk. Selain itu, walaupun pada awal pembelajaran guru telah menyampaik tujuan pembelajaran, siswa tetap saja tidak mengetahui tujuan pembelajaran yang dilaksanakan pada saat itu, karena guru hanya menekankan siswa pada aspek pengetahuan yang diberikan melalui penugasan yang menyebabkan kurangnya daya ingat siswa terhadap materi pembelajaran.

Pada prinsipnya bentuk dari kegiatan belajar adalah sebuah perbuatan. Yaitu berbuat merubah tingkah laku, untuk melakukan kegiatan. Kegiatan belajar tidak akan ada tanpa adanya aktivitas. Itulah sebabnya aktivitas merupakan prinsip atau asas penting di dalam kegiatan belajar mengajar. Sebagai rasionalisasinya hal ini juga mendapatkan pengakuan dari berbagai ahli pendidikan (Sardiman, 2012:96)

Sejalan dengan prinsip belajar diatas menurut Djamarah \& Aswan (2002:44) bahwa aktivitas belajar tersebut tidak hanya menuntut dari segi fisik saja melainkan juga dari segi kejiwaan. Bila aktivitas belajar bertumpu pada segi fisik, dan kurang aktif dari 
segi mental dan pikiran, maka tujuan dari pembelajaran kemungkinan tidak tercapai. Karena hal tersebut mrmbuat siswa tidak merasakan perubahan dalam dirinya. Dengan demikian sama saja dengan tidak belajar.

Menurut Noor Latifah dalam jurnal untan (Iman, 2013: 3), aktivitas siswa merupakan keterlibatan siswa dalam bentuk sikap, pikiran, perhatian dan aktivitas dalam kegiatan proses pembelajaran guna menunjang keberhasilan proses pembelajaran. Berlangsung atau tidaknya proses belajar mengajar seseorang itu akan bergantung pada dua hal yang mendahuluinya, yaitu bagaimana minat orang itu terhadap belajar, dan bagaimana orang itu beraktivitas ketika belajar. Dapat dikatakan bahwa aktivitas seseorang untuk berbuat sesuatu, salah satunya ditentukan oleh minat orang itu terhadap objek yang dihadapinya.

Jadi secara teoretik, dapat diasumsikan bahwa tinggi rendahnya aktivitas seseorang dalam belajar antara lain dapat juga dipengaruhi oleh minat orang itu mengenai proses belajar. Namun hal ini baru saja sekedar teori, sesuai dengan rencana penelitian penulis yang titik permasalahannya bertujuan untuk mengetahui sejauh mana keberadaan teori ini bila diterapkan pada kasus yang melibatkan siswa di SMP Negeri 2 Cileunyi..

Menurut Paul B. Diedrich dalam Sardiman (2012: 101) indikator yang menyatakan aktivitas siswa dalam belajar mengajar, yaitu:

a) Visual activities (Aktivitas Penglihatan). Misalnya membaca, melihat gambar, memperhatikan percobaan dan pekerjaan orang lain.

b) Oral activities (Aktivitas Lisan). Seperti menyatakan, merumuskan, bertanya, memberi saran, mengeluarkan pendapat, mengadakan wawancara, diskusi, interupsi.

c) Listening activities (Aktivitas Mendengar). Sebagai contoh mendengarkan uraian, percakapan, diskusi, musik, pidato.

d) Writing activities (Aktivitas Menulis). Seperti misalnya menulis cerita, karangan laporan, angket, menyalin.

e) Drawing activities (Aktivits Menggambar). Misalnya menggambar, membuat grafik, peta, diagram.

f) Motor activities (Aktivitas Gerak). Yang termasuk di dalamnya antara lain melakukan percobaan, membuat konstruksi, model mereparasi, bermain, berkebun, beternak.

g) Mental activities (Aktivitas Mental). Sebagai contoh misalnya: menanggap, mengingat, memecahkan soal, menganalisa, melihat hubungan, mengambil keputusan.

h) Emotional activities (Aktivitas Emosi). Seperti misalnya menaruh minat, merasa bosan, gembira, bersemangat, bergairah, berani, tenang, gugup.

Semua kegiatan tersebut merupakan bentuk dari aktivitas belajar siswa. Siswa diharapkan dapat berperan aktif dalam mencari sesuatu informasi guna memecahkan suatu permasalahan. Dalam pembelajaran bahasa Indonesia, banyak cara yang dapat dilakukan untuk menciptakan suasana belajar yang kondusif, dimana para siswa dapat 


\section{Diki Ibrahim}

mengembangkan aktivitas belajarnya secara optimal, sesuai dengan kemampuannya masing-masing.

Menurut Suryabrata (2013: 233), dalam belajar terdapat beberapa faktor yang dapat mempengaruhi aktivitas belajar siswa. Penggolongan faktor-faktor yang mempengaruhi proses belajar, antara lain: faktor-faktor yang berasal dari dalam diri siswa dan faktor- faktor yang berasal dari luar diri siswa.

a) Faktor Internal

Faktor internal adalah keadaan atau kondisi jasmani dan rohani siswa. Faktor yang berasal dari dalam diri individu siswa meliputi dua aspek, yaitu: 1) aspek fisiologis (yang bersifat jasmani). Aktivitas seorang akan bergantung manakala kesehatannya terganggu. Fisik yang sakit akan mempengaruhi kepada seluruh jaringan tubuh sehingga aktivitas tidak benar, keadaan sakit pada aspek fisik mengakibatkan seseorang cepat lelah, kurang bersemangat, mudah pusing dan sebagainya. Begitu juga halnya aktivitas siswa memerlukan kondisi tubuh yang kuat dan mental yang sehat. Karena dengan kondisi tersebut maka akan tercapai tujuan sesuai dengan apa yang diharapkan. 2) aspek psikologis (yang bersifat rohaniah). Aspek psikologi adalah yang berhubungan kejiwaan seseorang ini intelejensi, perhatian, minat, bakat emosi dan sebagainya. Faktor yang timbul dari siswa ini memegang peran yang sangat penting dalam menentukan keberhasilan siswa dalam belajar.

b) Faktor Eksternal

Faktor eksternal yakni kondisi lingkungan disekitar siswa (Syah, 2014:135). Lingkungan adalah segala sesuatu yang bermakna/ memberikan pengaruh terhadap individu, baik yang bersifat positif maupun negatif. Lingkungan meliputi lingkungan sosial, kultural dan alam dengan berbagai aspeknya.

Menurut Zakiah Darajat dalam (Kurdi dan Aziz, 2006: 6) pendidikan agama islam adalah usaha yang berupa bimbingan dan asuhan kepada siswa mengenai agama islam, agar jika pendidikannya telah selesai mereka memahami, menghayati, dan mengamalkan ajaran-ajaran agam islam yang telah diyakini secara menyeluruh, serta menjadikan ajaran agama islam sebagai pedoman hidupnya demi kebaikan kehidupan di dunia dan di akhirat.

Sedangkan menurut Ahmad D Marimba, pendidikan agama islam adalam suatu bimbingan baik jasmani maupun rohani yang berlandaskan hukum-hukum agama islam yang bertujuan untuk membentuk kepribadian siswa yang sesuai dengan ajaran agama islam (Kurdi dan Aziz, 2006:7).

Selain itu H.M. Arifin mengatakan bahwa pendidikan agama islam adalah suatu usaha sadar yang dilakukan oleh orang dewasa muslim yang bertakwa untuk mengarahkan dan membimbing pertumbuhan serta perkembangan fitrah (kemampuan dasar) siswa melalui ajaran agama islam ke arah titik maksimal pertumbuhan dan perkembangan (Kurdi dan Aziz, 2006:7).

Pengertian pendidikan agama islam secara formal merupakan upaya sadar dan terencana dalam menyiapkan siswa untuk mengenal, menghayati hingga mengimani, bertakwa, dan berakhlak mulia dalam mengamalkan ajaran agama islam dari sumber 
utamanya kitab suci al-Qur'an dan hadis, melalui kegiatan bimbingan, pengajaran, latihan serta penggunaan pengalaman. Yang disertai dengan tuntutan untuk menghormati penganut agama lain dalam masyarakat hingga terwujudnya kesatuan dan persatuan bangsa.

Majid (2012: 16), tujuan pendidikan agama Islam merupakan turunan dari tujuan pendidikan nasional yang terkandung dalam UUSPN No 20 tahun 2003, berbunyi: "Pendidikan nasional bertujuan untuk berkembangnya potensi peserta didik agar menjadi manusia yang beriman dan bertakwa kepada Tuhan Yang Maha Esa, berakhlak mulia, sehat, berilmu cakap, kreatif, mandiri, dan menjadi warga negara yang demokratis dan bertanggung jawab.

Dalam kehidupan sehari-hari, indikator tercapainya tujuan pendidikan agama islam adalah mencetak siswa yang mampu bergaul dengan sesama manusia dengan baik dan benar serta mengamalkan amar makruf nahi munkar kepada sesama manusia. Siswa yang telah dibimbing dengan pola pendidikan islam adalah siswa yang sukses dalam kehidupan karena ia memiliki kemampuan dan kemauan yang kuat untuk menjalani kehidupan berbekal ilmu-ilmu kesilaman yang diridai oleh Allah dan Rasul-Nya.

Pendidikan agama islam bertujuan untuk membangun karakter siswa yang kuat menghadapi berbagai cobaan dalam kehidupan, teliti dan sabar, serta cerdas dalam memecahkan masalah yang dihadapi.

Tujuan pendidikan agama islam dapat diuraikan secara sistematis sebagai berikut:

a) Terwujudunya siswa yang beriman dan bertakwa kepada Allah SWT,

b) Terwujudnya insan kamil, yang berakhlak karimah,

c) Terwujudnya insan yang cerdas dalam mengaji dan mengkaji ilmu pengetahuan,

d) Terwujudnya insan yang bermanfaat untuk kehidupan orang lain,

e) Terwujudnya insan yang sehat jasmani dan rohani, dan

f) Terwujudnya karekter muslim yang menyebarkan ilmunya kepada sesama manusia (Saebani dan Akhdiyat, 2009:147).

Dengan demikian tujuan dari Pendidikan Agama Islam ialah untuk membentuk karakter siswa yang memiliki akhlak mulia, memiliki pengetahuan yang luas, serta membangun pondasi keimanan dan ketakwaan siswa kepada Allah SWT.

Adapun ruang lingkup bahan pelajaran pendidikan agama islam di Sekolah pada umumnya terfokus pada aspek:

a) Al-Qur'an dan Hadis

b) Aqidah Akhlak

c) Fiqih

d) Sejarah Kebudayaan Islam

Ruang lingkup tersebut sekaligus menggambarkan bahwa pendidikan agama islam mencakup perwujudan keserasian, keselarasanm dan keseimbangan hubungan manusia dengan Allah SWT, diri sendiri, sesama manusia, makhluk lainnya maupun lingkungannya (Majid, 2011:13). 


\section{Diki Ibrahim}

Sehingga dapat disimpulkan bahwa pendidikan agama islam meliputi aspek pengetahuan yang meliputi Quran dan hadis, fiqih, dan sejarah, tetapi memfokuskan siswa juga pada sisi pengalaman dari pengetahuannya tersebut.

Berdasarkan uraian di atas, sebagai jawaban sementara terhadap penelitian ini yang kebenarannya harus di buktikan maka dirumuskan hipotesis penelitian ini sebagai berikut: "Adanya pengaruh yang signifikan terhadap aktivitas belajar siswa dengan menggunakan model pembelajaran Brain Based Learning".

\section{METODOLOGI PENELITIAN}

Metode yang digunakan pada penelitian ini adalah Quasi Experimental Design, yaitu penelitian yang bersifat semi eksperimen, karena tidak memungkinkan untuk melakukan eksperimen murni. Metode penelitian quasi eksperimen ini penelitan yang mempunyai kelompok kontrol, tetapi kelompok tersebut tidak dapat berfungsi sepenuhnya untuk mengontrol variabel-variabel luar yang mempengaruhi pelaksanaan eksperimen.

Adapun pendekatan yang digunakan dalam penelitian ini adalah Nonequivalent Control Group Design. Adapun pendekatan yang digunakan dalam penelitian ini adalah Nonequivalent Control Group Design. Pendekatan ini dilaksanakan dengan melakukan pretest pada kelas eksperimen dan kelas kontrol, lalu pemberian perlakuan khusus (treatment) pada kelas eksperimen saja yaitu dengan menggunakan model pembelajaran brain based learning, sedangkan pada kelas kontrol tidak diberi perlakuan khusus dengan menggunakan model pembelajaran konvensional, dan tahap terakhir ialah pemberian posttest pada kelas eksperimen dan kelas kontrol untuk mengetahui adakah perbedaan aktivitas belajar siswa yang diberi perlakuan khusus (treatment) model pembelajaran brain based learning dengan yang tidak diberi perlakuan khusus atau yang menggunakan model pembelajaran konvensional, berikut ini tabel desain penelitian nonequivalen control groupt design:

\begin{tabular}{|c|c|c|c|}
\hline Kelas & Pretest & Treatment & Posttest \\
\hline $\mathrm{E}$ & $\mathrm{O}_{1}$ & $\mathrm{X}$ & $\mathrm{O}_{2}$ \\
\hline $\mathrm{K}$ & $\mathrm{O}_{3}$ & & $\mathrm{O}_{4}$ \\
\hline
\end{tabular}

Table 1 Desain Penelitian

Keterangan :

$\mathrm{E}=$ kelas eksperimen

$\mathrm{O}_{1}=$ pretest pada kelas eksperimen sebelum diberi perlakuan

$\mathrm{O}_{2}=$ posttest pada kelas eksperimen setelah diberi perlakuan

$\mathrm{O}_{3}=$ pretest pada kelas kontrol

$\mathrm{O}_{4}=$ posttest pada kelas eksperimen

$\mathrm{X}=$ perlakuan terhadap kelas eksperimen

(Sugiyono, 2016:79)

Pelaksanaan penelitian ini dilaksanakan di SMP Negeri 2 Cileunyi yang terletak di Jl. Cibangbangan-Gamblung, Cileunyi Wetan, Cileunyi, Kabupaten Bandung, Jawa 
Barat 40622. Penelitian yang bertempat di SMP Negeri 2 Cileunyi ini dilaksanakan pada tanggal 5 Januari 2015 sampai dengan 2 Februari 2015. Adapun waktu penelitian disesuaikan dengan jadwal mata pelajaran Pendidikan Agama Islam dan Budi Pekerti pada kelas VII SMP Negeri 2 Cileunyi. Peneliti menggunakan waktu penelitian sebanyak dua kali pertemuan pada satu sub materi pembelajaran Pendidikan Agama Islam dan Budi Pekerti.

Adapun teknik pengumpulan data yang akan digunakan dalam penelitian ini adalah dengan cara peyebaran angket, wawanc.ara dan dokumentasi

Metode penelitian yang digunakan harus ditulis sesuai dengan cara ilmiah, yaitu rasional, empiris dan sistematis. Seyogyanya disebutkan waktu dan tempat penelitian secara jelas, berikut data maupun alat dan bahan yang dipakai dalam penelitian.

Sumber data primer yang diperoleh dari populasi siswa kelas VIII SMPN 2 Cileunyi, yang berjumlah 395 siswa yang terbagi ke dalam 10 kelas. Peneliti mengambil 2 kelas untuk dijadikan sebagai responden pada penelitian ini. Satu kelas tersebut akan menjadi kelas eksperimen dan satu kelas lagi untuk kelas kontrol. Sementara data sekunder diambil dari berbagai studi pustaka terkait model pembelajaran Brain Based Learning dan aktivitas belajar siswa.

\section{HASIL TEMUAN DAN PEMBAHASAN}

Berdasarkan hasil analisis data yang didapatkan, menunjukkan bahwa aktivitas belajar siswa di kelas eksperimen mengalami peningkatan dengan kategori tinggi. Hal tersebut sesuai dengan hasil dari rata-rata posttest aktivitas belajar siswa dengan menggunakan model pembelajaran Brain Based Learning yaitu sebesar 68,33. Aktivitas belajar siswa dapat dikategorikan tinggi, karena rata rata dari analisis angket perindikator didapat sebesar 3,70. Adapun secara lebih rinci, rata rata aktivitas visual siswa sebesar 3,47 yang dapat dikategorikan sedang. Selanjutnya aktivitas lisan rata-rata sebesar 3,59 dapat dikategorikan tinggi. Aktivitas mendengarkan sebesar 3,69 di interpretasikan tinggi. Aktivitas menulis sebesar 3,60 yang dikategorikan tinggi, Dan aktivitas emosi rata sebesar 4,17 dengan kategori tinggi.

\begin{tabular}{|c|c|c|}
\hline Sumber & Rata-rata Keseluruhan & Rata-rata Perindikator \\
\hline Posttest & 68,33 & 3,70 \\
\hline
\end{tabular}

Table 2 Rata-rata Posttest Kelas Eksperimen

Sebelum menggunakan model pembelajaran brain based learning, rata-rata aktivitas belajar siswa sebesar 53,76. Aktivitas belajar siswa pada saat pretest dapat dikategorikan sedang, karena rata rata dari analisis angket perindikator didapat sebesar 3,05. Adapun secara lebih rinci, rata rata aktivitas visual siswa sebesar 2,54 yang dapat dikategorikan sedang. Selanjutnya aktivitas lisan rata-rata sebesar 2,80. Aktivitas mendengarkan sebesar 3,30. Aktivitas menulis sebesar 2,91. Dan aktivitas emosi rata sebesar 3,68.

\begin{tabular}{l|l|l|} 
Sumber & Rata-rata Keseluruhan & Rata-Rata Perindikator \\
\hline
\end{tabular}


Diki Ibrahim

\begin{tabular}{|l|l|l|}
\hline Pretest & 53,76 & 3,05 \\
\hline
\end{tabular}

\section{Table 3 Rata-rata Pretest Kelas Eksperimen}

Dengan demikian aktivitas belajar siswa di kelas eksperimen menggalami peningkatan sebesar. Hal tersebut memberikan indikasi sejalan dengan strategi utama dari model pembelajaran brain based learning yang salah satunya adalah menciptakan pembelajaran yang aktif bagi siswa. Caine (2005: 6) (dalam jurnal AgriSains, Sukoco, 2014:154). Pembelajaran dengan model brain based learning dapat membuat siswa lebih percaya diri dan merasa relaks sehingga membuat siwa lebih aktif dalam pembelajaran.

Sementara itu aktivitas belajar siswa di kelas kontrol menunjukkan bahwa aktivitas belajar siswa di kelas kontrol tidak mengalami perubahan. Rata-rata aktivitas belajar siswa sebesar yang di dapat dari pretest yaitu sebesar 51,5. Aktivitas belajar siswa pada saat pretest dapat dikategorikan sedang, karena rata rata dari analisis angket perindikator didapat sebesar 2,94. Adapun secara lebih rinci, rata rata aktivitas visual siswa sebesar 2,46 yang dapat dikategorikan rendah. Selanjutnya aktivitas lisan rata-rata sebesar 2,76 dapat dikategorikan sedang. Aktivitas mendengarkan sebesar 3,24 berkategori sedang. Aktivitas menulis sebesar 2,88 dikategorikan sedang. Dan aktivitas emosi rata sebesar 3,37 berkategori sedang.

\begin{tabular}{|l|c|c|}
\hline Sumber & Rata-rata Keseluruhan & $\begin{array}{c}\text { Rata-Rata } \\
\text { Perindikator }\end{array}$ \\
\hline Pretest & 51,5 & 2,94 \\
\hline
\end{tabular}

Table 4 Rata-rata Pretest Kelas Kontrol

Sedangkan saat posttest rata-rata aktivitas belajar siswa sedikit menurun yaitu sebesar 50,67. Aktivitas belajar siswa saat posttest dikelas kontrol dikategorikan sedang, karena rata rata dari analisis angket perindikator didapat sebesar 2,92. Adapun secara lebih rinci, rata rata aktivitas visual siswa sebesar 2,59 yang dapat dikategorikan sedang. Selanjutnya aktivitas lisan rata-rata sebesar 2,80 dapat dikategorikan sedang. Aktivitas mendengarkan sebesar 3,01 di interpretasikan sedang. Aktivitas menulis sebesar 2,97 yang dikategorikan sedang, Dan aktivitas emosi rata sebesar 3,24 dengan kategori sedang. Dengan demikian aktivitas belajar siswa di kelas kontrol tidak mengalam perubahan, adapun tingkat dari aktivitas belajar siswa di kelas kontrol dikategorikan sedang.

\begin{tabular}{|l|c|c|}
\hline Sumber & Rata-rata Keseluruhan & Rata-rata Perindikator \\
\hline Posttest & 50,67 & 2,92 \\
\hline
\end{tabular}

Table 5 Rata-rata Postest Kelas Kontrol

Dengan demikian sebagaimana menurut Sanjaya (2011: 261) dalam jurnal hasil penelitian laksmi (2014) menyebutkan bahwa dengan model pembelajaran konvensional, siswa akan merasakan pembelajaran yang dilaksanakan kurang 
bermakna, karena siswa lebih banyak belajar secara individual dengan menerima, mencatat, dan menghafal materi pelajaran. Oleh karena itu tidak heran jika aktivitas belajar siswa di kelas hanya pada level sedang atau bahkan rendah.

Adapun hasil uji-t dari pretest kedua kelas tidak memiliki perbedaan yang signifikan. Rata rata angket pretes kelas eksperimen yaitu 53,76 dan kelas kontrol 51,5. Jika di analisis perindikator, rata rata aktivitas belajar siswa dikedua kelas tersebut dikategorikan sedang.

Setelah itu peneliti melaksanakan pembelajaran dan memberikan perlakuan kepada kelas eksperimen dengan menggunakan model pembelajaran brain based learning. Pelaksaan penelitian tersebut dilaksanakan sebanyak 2 kali pertemuan dengan bahasan pokok pembelajaran sejarah pertumbuhan ilmu pada masa abbasiyah. Selanjutnya peneliti memberikan angket yang sama untuk mengetahui bagaimana aktivitas belajar siswa setelah diberi perlakuan. Adapun rata rata angket posttest di kelas eksperimen sebesar 68,33 sedangkan rata rata angket posttest di kelas kontrol sebesar 50,67 .

Adapun hasil uji-t dari posttest kedua kelas memiliki perbedaan yang signifikan. Rata rata angket pretes kelas eksperimen yaitu 68,33 dan kelas kontrol 50,67. Jika di analisis perindikator, rata rata aktivitas belajar siswa di kelas eksperimen dikategorikan tinggi. Sedangkan aktivitas belajar siswa di kelas kontrol dikategorikan sedang.

\begin{tabular}{|c|c|c|c|c|}
\hline \multirow{2}{*}{ Kelas } & \multicolumn{2}{|c|}{ Uji Homogenitas } & \multicolumn{2}{|c|}{ Uji-T } \\
\hline & Pretest & Posttest & Pretest & Posttest \\
\hline Eksperimen & \multirow{2}{*}{1,034} & \multirow{2}{*}{1,637} & \multirow{2}{*}{1,083} & \multirow{2}{*}{2,022} \\
\hline Kontrol & & & & \\
\hline Keterangan & \multicolumn{2}{|c|}{ Homogen } & $\begin{array}{c}\text { Tidak ada perbedaan } \\
\text { yang signifikan }\end{array}$ & $\begin{array}{c}\text { Terdapat perbedaan } \\
\text { yang signifikan }\end{array}$ \\
\hline
\end{tabular}

\section{Table 6 Rekapitulasi Uji Homogenitas dan Uji-T}

Sementara itu hasil dari Uji N-gain menunjukkan bahwa perubahan yang terdapat pada kelas eksperimen dikategorikan sedang karena hasil $\mathrm{N}$-gain dikelas eksperimen yaitu sebesar 0,56. Sedangkan hasil $\mathrm{N}$-gain pada kelas kontrol yaitu sebesar 0,023. Dengan demikian dapat disimpulkan bahwa model pembelajaran brain based learning memiliki pengaruh terhadap aktivitas belajar siswa.

\begin{tabular}{|c|c|c|}
\hline Kelas & N-Gain & Interpretasi \\
\hline Eksperimen & 0,56 & Sedang \\
\hline Kontrol & 0,023 & Rendah \\
\hline
\end{tabular}

Table 7 Rekapitulasi Uji N-gain

Jensen (2011) yang dikutip laksmi (2014) menyatakan bahwa tida strategi utam dari model pembelajaran brain based learning adalah menciptakan lingkungan belajar 


\section{Diki Ibrahim}

yang menantang kemampuan berpikir siswa, menciptakan pembelajaran yang menyenangkan, dan menciptakan pembelajaran yang aktif.

Sesuai dengan pernyataan tersebut bahwa model pembelajaran brain based learning mampu menciptakan pembelajaran yang aktif bagi siswa. Hal tersebut sejalan dengan hasil dari penelitian skripsi ini yang menunjukkan bahwa aktivitas belajar siswa yang menggunakan model pembelajaran brain based learning menghasilkan rata rata aktivitas belajar siswa sebesar 68,33, hasil tersebut mengalami kenaikan dari semula sebelum menggunakan model ini dengan rata-rata 53,76.

\section{SIMPULAN}

Berdasarkan hasil penelitian dan pembahasan mengenai pengaruh model pembelajaran brain based learning terhadap aktivitas belajar siswa pada mata pelajara PAI di SMPN 2 Cileunyi, penulis menarik kesimpulan sebagai berikut:

1. Realitas aktivitas belajar siswa pada mata pelajaran PAI dengan menggunakan model pembelajaran brain based learning pada kelas eksperimen dapat dikategorikan tinggi. Hal tersebut dilihat dari hasil perhitungan statistik penyebaran angket kepada 33 siswa dengan 20 pertanyaan yang menghasilkan rata-rata 3,70. Angka tersebut dapat diinterpretasikan tinggi karena berada pada interval 3,50 - 4,50. Nilai N-gain kelas eksperimen 0,56 yang diinterpresikan sedang. Hal ini berarti bahwa aktivitas belajar siswa mengalami perubahan sebelum menggunakan model pembelajaran brain based learning dan setelah menggunakan model pembelajaran brain based learning dalam kategori sedang.

2. Realitas aktivitas belajar siswa pada mata pelajaran PAI dengan menggunakan model pembelajaran konvensional pada kelas kontrol dapat dikategorikan sedang. Hal tersebut di lihat dari hasil perhitungan statistik penyebaran angket kepada 30 siswa dengan 20 pertanyaan yang memiliki hasil rata-rata 2,92. Angka tersebut dapat diinterpretasikan sedang karena berada pada interval 2,50 - 3,50. Dan nilai N-gain kelas kontrol yaitu sebesar 0,023 yang diinterpresikan rendah. Hal ini menunjukkan aktivitas belajar siswa pada kelas kontrol tidak mengalami perubahan.

3. Realitas pengaruh penerapan model pembelajaran brain based learning terhadap aktivitas belajar siswa Kelas VIII SMPN 2 Cileunyi pada Mata Pelajaran PAI mengalami perubahan yang signifikam, hal ini di lihat dari hasil pengujian hipotesis dengan taraf signifikansi $5 \%$ menujukan hasil $t_{\text {hitung }} 2,022>t_{\text {tabel }} 1,999$. Dengan demikian, artinya ada pengaruh yang signifikan model pembelajaran brain based learning terhadap aktivitas belajar siswa. Adapun pengaruh tersebut sesuai dengan hasil perhitungan $\mathrm{N}$-gain yaitu sebesar 0,56 , angka tersebut termasuk pada kategori sedang karena berada pada interval 0,30 - 0,70 yang berarti pengaruh dari model pembelajaran brain based learning terhadap aktivitas belajar siswa memiliki pengaruh yang diinterpretasikan sedang sesuai dengan kriteri $\mathrm{N}$-gain menurut Susanto (2012: 75). 


\section{DAFTAR PUSTAKA}

Aulia, T. R. (2009). Himpunan Perundang-undanga RI tentang Sistem Pendidikan Nasional. Bandung: Nuansaaulia.

Given, B. K. (2007). Brain Based Teaching. Bandung: Kaifa.

Iman. (2013). Peningkatan Aktivitas Belajar Siswa dalam Pembelajaran Ilmu Pengetahuan Alama dengan Menggunakan Metode Demonstrasi. Jurnal Untan.

Jensen, E. (2008). Brain Based Learning. Yogyakarta: Pustaka Pelajar.

Kemendikbud. (2016). Model Silabus Mata Pelajaran Sekolah Menengah Pertama/Madrasah Tsanawiyah (SMP/MTs). Jakarta: Kemendikbud.

Kurdi, S., \& Aziz, A. (2006). Model Pembelajaran Efektif Pendidikan Agama Islam Di Sekolah Dasar dan MI. Bandung: Pustaka Bani Quraisy.

Laksmi, \& dkk. (2014). Pengaruh Model Pembelajaran Berbasis Otak (Bran Based Learning) Berbantuan Media Teka-Teki Silang terhadap Hasil Belajar IPS Siswa Kelas V SD Gugus I Gusti Ngurah Jelantik. Jurnal Mimbar PGSD Universitas Pendidikan Ganesha.

Lusa, R. (2014). Perbedaan Pengaruh Model E-Learning dan Konvensional Terhadap Hasil Belajar Dan Keterampilan Praktik Menyusui Benar. Jurnal Kesehatan "Samodra Ilmu".

Majid, A. (2012). Belajar dan Pembelajaran Pendidikan Agama Islam. Bandung: PT Remaja RosdaKarya.

Saebani, B. A., \& Hendra, A. (2009). Ilmu Pendidikan Islam. Bandung: Pustaka Setia. Sardiman. (2010). Interaksi dan Motivasi Belajar Mengajar. Jakarta: Rajawali Pers.

Setiyowati, E. A., \& Pramukantoro, J. A. (2014). Model Pembelajaran Kooperatif Murder Untuk Meningkatkan Hasil Belajar Siswa pada Kompetensi Inti Teknik Elektronika di SMK Negeri 1 Nganjuk. Jurnal Pendidikan Teknik Elektro.

Sugiyono. (2016). Metode Penelitian Kuantitatif, Kualitatif, dan R\&D. Bandung: Alfabeta.

Sukoco, H. (2014). Efektivitas Pendekatan Brain Based Learning (BBL) Ditinjau dari Kemampuan Komunikasi Matematis Siswa. Jurnal AgriSains.

Suryabrata, S. (2013). Psikologi Pendidikan. Jakarta: Rajawali Pers.

Suryana, Y., \& Priatna, T. (2007). Metode Penelitian Pendidikan. Bandung: Azkia Pustaka Utama.

Syah, Muhibin. (2014). Psikologi Pendidikan Dengan Pendekatan Baru. Bandung: Remaja Rosdakarya.

Tatang. (2012). Ilmu Pendidikan. Bandung: Pustaka Setia.

Ur-Rehman, A., Malik, M. A., Hussain, S., Iqbal, Z., \& Ruf, M. (2012). Effectiveness of Brain-Based Learning Theory on Secondary Level Students of Urban Areas. Journal of Managerial Sciences, 113-122. 